\title{
Deoxysphingolipids as candidate biomarkers for a novel SPTLC1 mutation associated with HSAN-I
}

Federica Boso, MD, Andrea Armirotti, PhD, Federica Taioli, MSc, Moreno Ferrarini, PhD, Lucilla Nobbio, BSc, PhD, Tiziana Cavallaro, MD, and Gian Maria Fabrizi, MD, PhD

Neurol Genet 2019;5:e365. doi:10.1212/NXG.0000000000000365

Hereditary sensory and autonomic neuropathy type 1 (HSAN-I) — an autosomal dominant, mainly sensory neuropathy - typically affects patients in their second and third decades, presenting with ulcerations and lancinating pain attacks. ${ }^{1}$ Diagnosis is heavily dependent on genetic analysis, focusing on 6 genes: serine palmitoyltransferase (SPT) long chain base subunits 1 and 2 (SPTLC1 and SPTLC2), atlastin 1 (ATL1) and 3 (ATL3), DNA methyltransferase 1, and Ras-related protein (RAB7). Most patients carry SPTLC1 mutations $\left(\mathrm{OMIM}^{*} 605712\right)$ that affect sphingolipids biosynthesis by modifying SPT substrate specificity to produce atypical neurotoxic deoxysphingoid bases (DSBs). Along with their accumulation in mutant cells, elevated DSBs were also found in plasma samples, thus becoming a candidate biomarker of disease. ${ }^{2}$

We identified a novel SPTLC1 missense mutation in a 22-year-old white male patient with early onset of sensory loss. Pathologic and familiar anamnesis was negative, except for isoniazid/ pyridoxine chemoprophylaxis, not reaching neurotoxic doses. Sensory alterations were initially subtle with gradual loss of tactile and thermo-dolorific sensation on lower limbs, resulting in repetitive foot ulcerations that required surgical treatment and evolved into Pseudomonas osteomyelitis; of interest, the subject reported neither pain or positive sensory symptoms nor difficulties in motor performances throughout adolescence.

On examination, the patient had pronounced deep and-primarily-superficial sensory disturbances up to his knees after receiving anesthesia in his toes. Muscle strength was preserved; deep tendon reflexes were normal for upper extremities, while he had sluggish patellar reflexes and no ankle jerks. He also had pronated feet with hammer toes and signs of cutaneous dystrophy with nail alterations.

Nerve conduction studies disclosed an axonal, sensory-motor, length-dependent neuropathy (see supplemental data, links.lww.com/NXG/A186). No laser evoked potentials were detected after lower and upper limb stimulation. Autonomic functions were also evaluated with sympathetic skin reflex, Sudoscan, and cardiovascular testing, reporting no significant alteration.

Sural nerve biopsy showed a chronic axonal process with almost complete loss of myelinated fibers and no evidence of active degeneration or clusters of regenerating fibers (figure, A). ${ }^{3}$ Ultrastructural study disclosed a severe loss of unmyelinated fibers, atrophic and denervated Schwann cell processes, and remarkable absence of collagen pockets (figure, B). Immunofluorescence microscopy of skin biopsy at distal calf also revealed rare intraepidermal nerve fibers.
Correspondence

Dr. Fabrizi

gianmaria.fabrizi@univr.it

From the Department of Neuroscience (F.B., F.T., M.F., T.C., G.M.F.), Biomedicine and Movement Sciences, University of Verona; Department of Neurosciences (F.B., F.T., M.F., T.C., G.M.F.), AOUI Verona; Analytical Chemistry Lab (A.A.), Fondazione Istituto Italiano di Tecnologia; and Department of Neurosciences (L.N.), Rehabilitation, Ophthalmology, Genetics and Maternal-Infantile Sciences, University of Genoa \& IRCCS Ospedale Policlinico San Martino, Genova, Italy.

Go to Neurology.org/NG for full disclosures. Funding information is provided at the end of the article.

The Article Processing Charge was funded by the authors.

This is an open access article distributed under the terms of the Creative Commons Attribution-NonCommercial-NoDerivatives License 4.0 (CC BY-NC-ND), which permits downloading and sharing the work provided it is properly cited. The work cannot be changed in any way or used commercially without permission from the journal. 

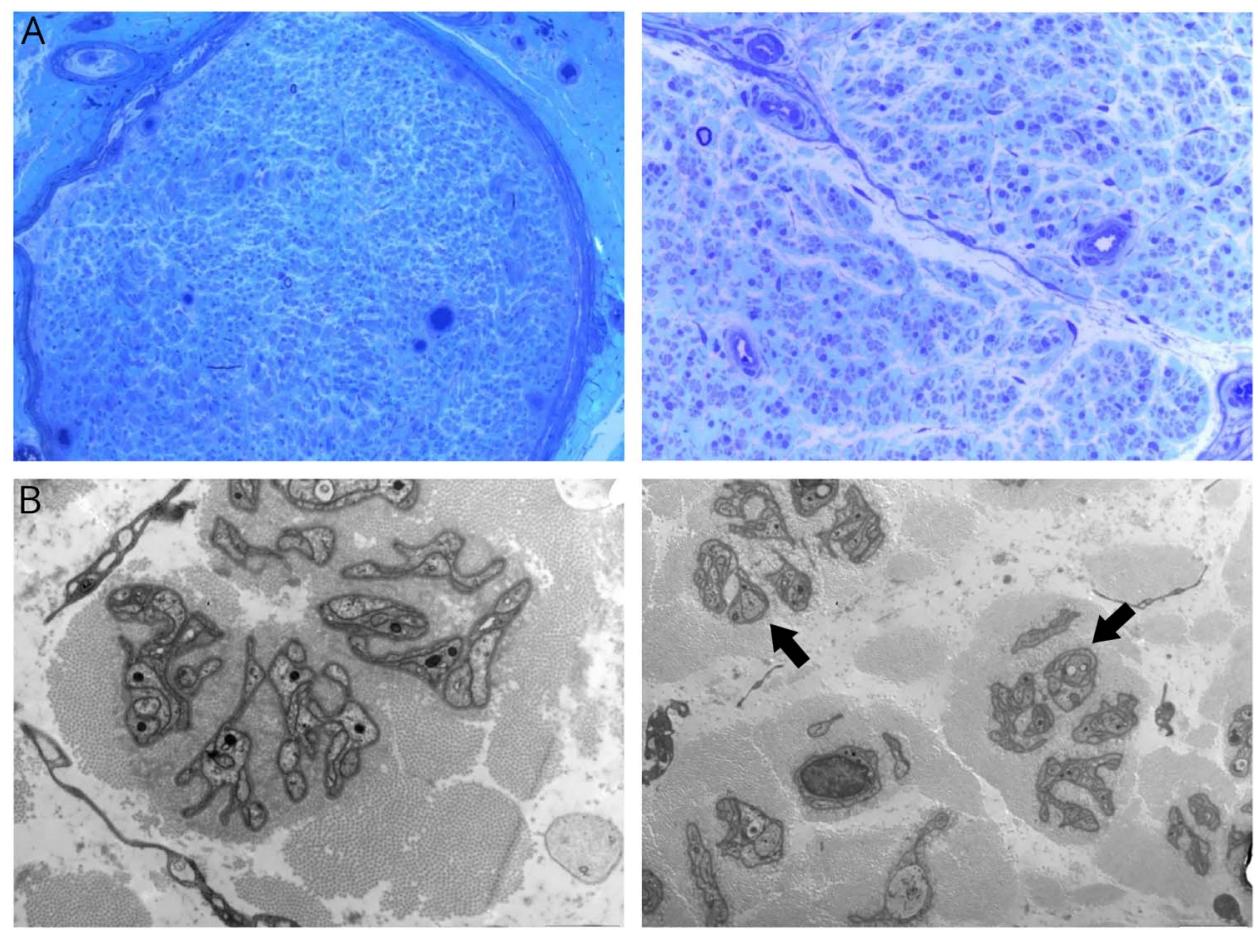

C

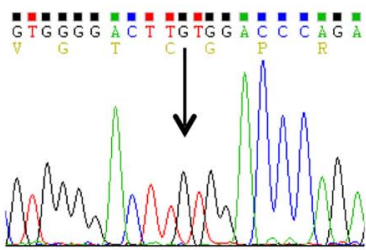

Father

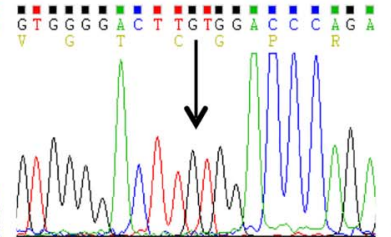

Mother

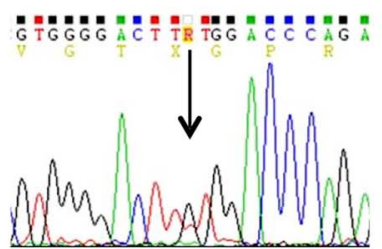

Proband

$\mathrm{D}$

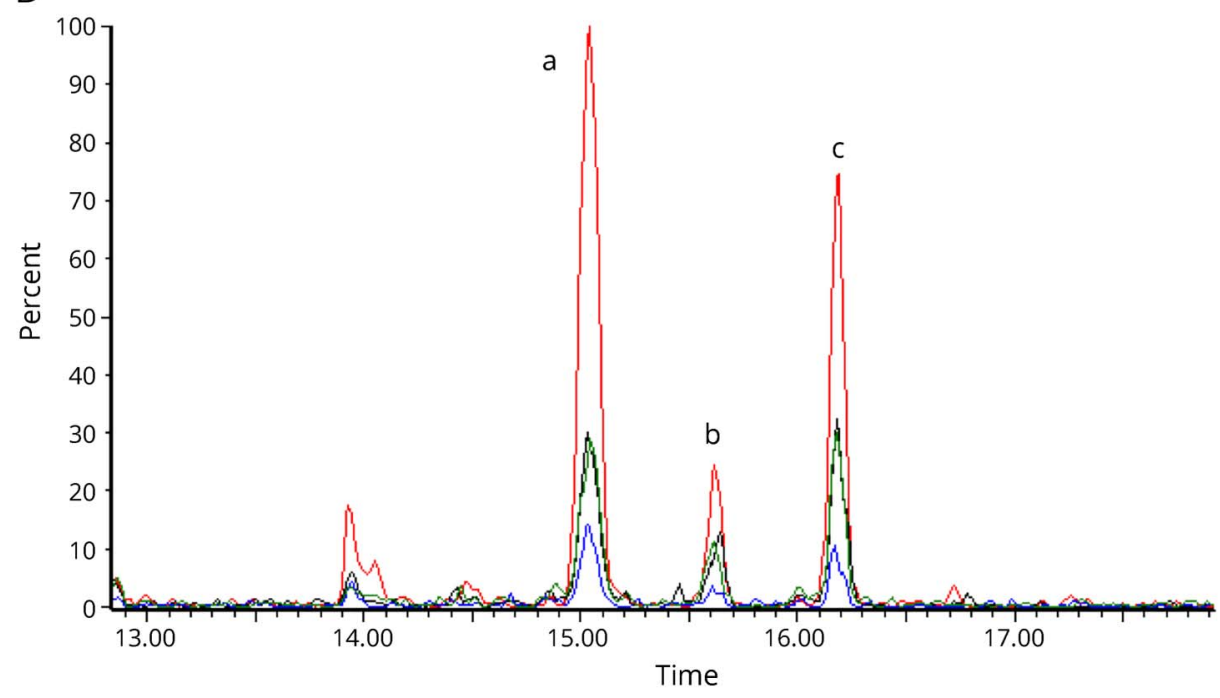

(A) Sural nerve biopsy, semithin section: the biopsy showed a chronic axonal neuropathy pattern with remarkable loss of myelinated fibers without signs of degeneration or regeneration. Note that the few detectable fibers have a normal myelin sheath (original magnification: left picture 10x; right picture 40x). (B) Electron microscopy (7000×): ultrastructural study showed rare umyelinated fibers (indicated by arrows) with many denervated Schwann cel processes. Note the absence of collagen pockets. (C) Next-generation sequencing with an in-house panel targeted on 45 genes associated with hereditary, predominantly sensory neuropathies was performed on a PGM Ion Torrent machine (Thermo Fisher Scientific), disclosing a novel mutation in SPTLC1 that was absent in both healthy parents and the proband's brother. The mutation was further characterized by Sanger sequencing, demonstrating a heterozygous c.398G > T mutation in SPTLC1 exon 5 causing a p.Cys133Phe (alias p.C133F) substitution, as shown in this panel. In silico analysis predicted a pathogenic relevance of this substitution (PolyPhen-2: 1.0; SIFT score: 0.0; MutationTaster: "disease causing") because it involves a phylogenetically conserved amino acid in a mutational hot spot. Indeed, most mutations associated with hereditary sensory and autonomic neuropathy type phenotype are located at the monomer-monomer interface and cluster around the pyridoxal-5'phosphate binding domain; thus, the substitution of a polar residue with a hydrophobic one at this level may affect enzyme's structure by changing substrate specificity, in analogy to previously described pathologic variants at the same Cys133 residue (Cys133Trp, Cys133Tyr, and Cys133Arg). (D) Plasma liquid chromatographymass spectrometry untargeted lipidomic analysis: extracted chromatograms of fragment ion 268.30 $\mathrm{m} / \mathrm{z}$, diagnostic for the deoxysphingosine moiety. The 3 peaks correspond to 3 different eluting deoxyceramides. a: $\operatorname{Cer}(\mathrm{m} 18: 0 / 22$ $0)$; b: $\operatorname{Cer}(\mathrm{m} 18: 0 / 23: 0) ; \mathrm{c}: \operatorname{Cer}(\mathrm{m} 18$ : $0 / 24: 0$ ). The plot reports the proband subject (in red) vs 3 asymptomatic relatives (father: blue mother: green; brother: black). PGM = Personal Genome Machine; SIFT $=$ Sorting Intolerant From Tolerant.
Next-generation sequencing with an in-house panel targeted on 45 Charcot-Marie-Tooth disease (CMT) and sensory CMT-related genes disclosed a SPTLC1 mutation that was absent in both healthy parents and the proband's brother (wild-type allele). The heterozygous c.398G $>\mathrm{T}$ transversion caused a p.Cys133Phe substitution, not previously described 
in reference databases (Exome Aggregation Consortium, Exome Variant Server, and 1000 Genomes), nor in the Human Gene Mutation Database (figure, C). In silico analysis predicted its pathogenic relevance, as it involves a phylogenetically conserved amino acid in a mutational hot spot, and the substitution of a polar residue with a hydrophobic one may affect the enzyme structure by changing substrate specificity, in analogy to other previously described pathogenic variants at the same residue (Cys133Trp, Cys133Tyr, and Cys133Arg).

The mutation functional impact was also addressed with untargeted lipidomic analysis (see supplemental data, links. lww.com/NXG/A186), detecting abnormally high levels of 3 deoxyceramides (22:0, 23:0, and 24:0) in the proband's plasma samples, compared with asymptomatic relatives (mother, father, and brother; figure, D). The aberrant m18: 0 deoxysphingosine species were identified by their diagnostic MS/MS fragment ion $\left(280.30 \mathrm{~m} / \mathrm{z}^{4}\right)$, thus reinforcing the hypothesis of SPT incorporating alanine into sphingolipids. On the other hand, we did not observe any significant proof of glycine use as an alternative substrate, as there were no corresponding m17:0 sphingoid bases (fragment ion $253.27 \mathrm{~m} / z$ ).

In conclusion, we identified a novel SPTLC1 mutation associated with early-onset, fairly typical HSAN1, despite the absence of pain attacks. Besides neurophysiologic and pathologic data, genetic interpretation and biochemical evidence strengthen the hypothesis of p.Cys133Phe pathogenicity, reflecting the mutant enzyme's ability to incorporate alanine instead of serine to generate atypical DSB. The pathologic mechanisms of their toxicity are still unanswered, ${ }^{5}$ but it is intriguing to note that high DSB levels have also been detected in patients with diabetic and paclitaxel induced neuropathy, suggesting a possible common neurotoxic effect to explain the clinical similarities of these neuropathies. Furthermore, DSB plasma measures could become a new diagnostic and prognostic marker, all the more so since HSAN1 might be a potentially treatable neuropathy through modulation of deoxysphingolipid formation by amino acid availability. In particular, L-serine supplementation could reduce disease severity and progression by limiting DSB accumulation (as already shown in mouse models ${ }^{6}$ and a recent clinical tri$\mathrm{al}^{7}$ ), thus urging early diagnosis of HSAN1 from a genetic and biochemical point of view, especially for patients with atypical mutations.

\section{Study funding}

No targeted funding reported.

\section{Disclosure}

Disclosures available: Neurology.org/NG.

\section{Publication history}

Received by Neurology: Genetics March 29, 2019. Accepted in final form August 22, 2019.

\section{Appendix Authors}

\begin{tabular}{|c|c|c|c|}
\hline Name & Location & Role & Contribution \\
\hline $\begin{array}{l}\text { Federica } \\
\text { Boso, MD }\end{array}$ & $\begin{array}{l}\text { Department of } \\
\text { Neuroscience, } \\
\text { Biomedicine and } \\
\text { Movement Sciences, } \\
\text { University of Verona, } \\
\text { Verona, Italy }\end{array}$ & Author & $\begin{array}{l}\text { Data acquisition and } \\
\text { data analysis and } \\
\text { drafting the } \\
\text { manuscript }\end{array}$ \\
\hline $\begin{array}{l}\text { Andrea } \\
\text { Armirotti, } \\
\text { PhD }\end{array}$ & $\begin{array}{l}\text { Analytical Chemistry } \\
\text { Lab, Fondazione } \\
\text { Istituto Italiano di } \\
\text { Tecnologia, Genova, } \\
\text { Italy }\end{array}$ & Author & $\begin{array}{l}\text { Major role in the } \\
\text { acquisition of LC-MS/ } \\
\text { MS data and revised } \\
\text { the manuscript for } \\
\text { intellectual content }\end{array}$ \\
\hline $\begin{array}{l}\text { Federica } \\
\text { Taioli, MSc }\end{array}$ & $\begin{array}{l}\text { Department of } \\
\text { Neuroscience, } \\
\text { Biomedicine and } \\
\text { Movement Sciences, } \\
\text { University of Verona, } \\
\text { Verona, Italy }\end{array}$ & Author & $\begin{array}{l}\text { Major role in the } \\
\text { acquisition and } \\
\text { interpretation of } \\
\text { genetic data }\end{array}$ \\
\hline $\begin{array}{l}\text { Moreno } \\
\text { Ferrarini, } \\
\text { PhD }\end{array}$ & $\begin{array}{l}\text { Department of } \\
\text { Neuroscience, } \\
\text { Biomedicine and } \\
\text { Movement Sciences, } \\
\text { University of Verona, } \\
\text { Verona, Italy }\end{array}$ & Author & $\begin{array}{l}\text { Data acquisition and } \\
\text { analysis }\end{array}$ \\
\hline $\begin{array}{l}\text { Lucilla } \\
\text { Nobbio, } \\
\text { BSc, PhD }\end{array}$ & $\begin{array}{l}\text { Department of } \\
\text { Neurosciences, } \\
\text { Rehabilitation, } \\
\text { Ophthalmology, } \\
\text { Genetics and } \\
\text { Maternal-Infantile } \\
\text { Sciences, University of } \\
\text { Genoa \& IRCCS } \\
\text { Ospedale Policlinico } \\
\text { San Martino, Genova, } \\
\text { Italy. }\end{array}$ & Author & $\begin{array}{l}\text { Critical revision of the } \\
\text { manuscript }\end{array}$ \\
\hline $\begin{array}{l}\text { Tiziana } \\
\text { Cavallaro, } \\
\text { MD }\end{array}$ & $\begin{array}{l}\text { Department of } \\
\text { Neuroscience, } \\
\text { Biomedicine and } \\
\text { Movement Sciences, } \\
\text { University of Verona, } \\
\text { Verona, Italy }\end{array}$ & Author & $\begin{array}{l}\text { Major role in the } \\
\text { acquisition and } \\
\text { interpretation of } \\
\text { neuropathologic data } \\
\text { and revised the } \\
\text { manuscript for } \\
\text { intellectual content }\end{array}$ \\
\hline $\begin{array}{l}\text { Gian } \\
\text { Maria } \\
\text { Fabrizi, } \\
\text { MD, PhD }\end{array}$ & $\begin{array}{l}\text { Department of } \\
\text { Neuroscience, } \\
\text { Biomedicine and } \\
\text { Movement Sciences, } \\
\text { University of Verona, } \\
\text { Verona, Italy }\end{array}$ & Author & $\begin{array}{l}\text { Conceptualized the } \\
\text { study, data acquisition } \\
\text { and analysis, and } \\
\text { writing of the } \\
\text { manuscript }\end{array}$ \\
\hline
\end{tabular}

\section{References}

1. Auer-Grumbach M, De Jonghe P, Verhoeven K, et al. Autosomal dominant inherited neuropathies with prominent sensory loss and mutilations: a review. Arch Neurol 2003;60:329-334.

2. Houlden H, Bull K, Murphy SM, et al. Hereditary sensory and autonomic neuropathy type 1: correlation of severity and plasma atypical deoxy-sphyngoid bases. J Neurol Neurosurg Psychiatry 2012;83(suppl 2):1042.

3. Houlden H, King R, Blake J, et al. Clinical, pathological and genetic characterization of hereditary sensory and autonomic neuropathy type 1 (HSAN I). Brain 2006;129:411-425.

4. Zitomer NC, Mitchell T, Voss KA, et al. Ceramide synthase inhibition by fumonisin B1 causes accumulation of 1-deoxysphinganine. A novel category of bioactive 1-deoxysphingoid bases and 1-deoxydihydroceramides biosynthesized by mammalian cell lines and animals. J Biol Chem 2009;284:4786-4795.

5. Reilly MM, Greensmith L, Wilson ER, et al. Hereditary sensory neuropathy type 1associated deoxysphingolipids cause neurotoxicity, acute calcium handling abnormalities and mitochondrial dysfunction in vitro. Neurobiol Dis 2018;117:1-14.

6. Garofalo K, Penno A, Schmidt BP, et al. Oral 1 -serine supplementation reduces production of neurotoxic deoxysphingolipids in mice and humans with hereditary sensory autonomic neuropathy type 1. J Clin Invest 2011;121:14-16.

7. Fridman V, Suriyanarayanan S, Novak P, et al. Randomized trial of l-serine in patients with hereditary sensory and autonomic neuropathy type 1. Neurology 2019;92: e359-e370. 


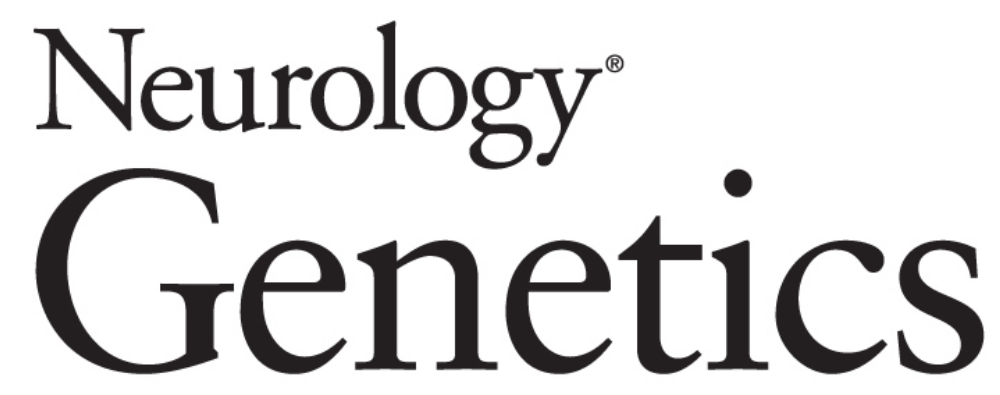

\section{Deoxysphingolipids as candidate biomarkers for a novel SPTLC1 mutation associated with HSAN-I}

Federica Boso, Andrea Armirotti, Federica Taioli, et al. Neurol Genet 2019;5;e365

DOI 10.1212/NXG.0000000000000365

\section{This information is current as of October 8, 2019}

\section{Updated Information \& Services}

References

Citations

Subspecialty Collections

Permissions \& Licensing

Reprints including high resolution figures, can be found at: http://ng.neurology.org/content/5/6/e365.full.html

This article cites 7 articles, 1 of which you can access for free at: http://ng.neurology.org/content/5/6/e365.full.html\#\#ref-list-1

This article has been cited by 1 HighWire-hosted articles: http://ng.neurology.org/content/5/6/e365.full.html\#\#otherarticles

This article, along with others on similar topics, appears in the following collection(s):

\section{All Genetics}

http://ng.neurology.org//cgi/collection/all_genetics

Peripheral neuropathy

http://ng.neurology.org//cgi/collection/peripheral_neuropathy

Information about reproducing this article in parts (figures,tables) or in its entirety can be found online at:

http://ng.neurology.org/misc/about.xhtml\#permissions

Information about ordering reprints can be found online: http://ng.neurology.org/misc/addir.xhtml\#reprintsus

Neurol Genet is an official journal of the American Academy of Neurology. Published since April 2015, it is an open-access, online-only, continuous publication journal. Copyright Copyright $\odot 2019$ The Author(s). Published by Wolters Kluwer Health, Inc. on behalf of the American Academy of Neurology.. All rights reserved. Online ISSN: 2376-7839.

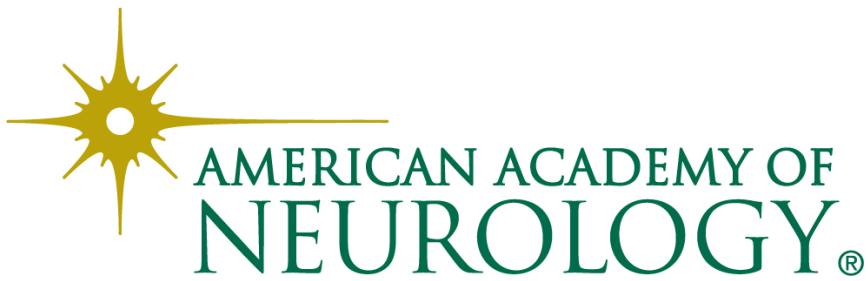

